Aurel Nuro,, Elda Marku, Bledar Murtaj

Tirana University, Faculty of Natural Sciences, Chemistry Department, Tirana, Albania
Scientific paper

ISSN 0351-9465, E-ISSN 2466-2585

UDC:628.4.113.161(282)(496.5)

doi:10.5937/zasmat $1804475 \mathrm{~N}$

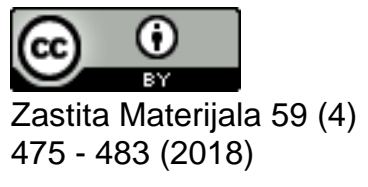

\title{
Organochlorine pesticides and their residues in surface waters of Albania
}

\begin{abstract}
This study presents concentrations of organochlorine pesticides and their residues in some water ecosystems of Albania. The water samples were collected in three ports of Adriatic Sea (Ports of Vlora, Durres and Porto-Romano), in four rivers (Semani, Shkumbini, Erzeni and Mati rivers) and two main lagoons of Albania (Karavasta and Patoku lagoons). 117 water samples were analyzed for a two years period (March 2014 - April 2016). Qualitative and quantitative analyze of 31 organochlorine pesticides and their residues based on EPA $8081 B$ Method were realized using technique of gas chromatography with electron capture detector. RTX-5 capillary column was used for separation of organochlorine compounds.

The higher concentrations of organochlorine pesticides were found for water samples of Shkumbini River, Semani River and Karavasta Lagoon because of their previous use. Residues of pesticides were in higher level than pesticides because degradation processes. Some individual pesticides were found in higher concentrations in some stations. This could be because of punctual sources or recent use for these pesticides. Organochlorine pesticides concentrations were found to be in lower levels than reported data on previous studies for the same stations.
\end{abstract}

Keywords: Organochlorine pesticides; Adriatic Sea; Albanian rivers; lagoons; water analyze; GC/ECD.

\section{INTRODUCTION}

Albania is a country rich in marine and surface waters. It is situated in western part of Balkan Peninsula facing the Adriatic Sea and the Ionian Sea. The coastal area has a surface area of 7000 $\mathrm{km}^{2}$ (25\% of the territory). The total coast line is $427 \mathrm{~km}$ (273 km part of Adriatic Sea). Marine and coastal environment constitutes resources of high economic and ecological values for the country [13].

About 60 wetland ecosystems are known in Albania (mostly in Adriatic Sea coastline), with a total area of $109 \mathrm{~km}^{2}$. These lagoons are areas of multiple ecological and economic values. They provide fish and wildlife habitats, support complex food web, absorb water to reduce flooding and damage from storms, provide erosion control, improve the

\footnotetext{
${ }^{*}$ Corresponding author: Aurel Nuro

E-mail: aurel.nuro@fshn.edu.al

Paper received: 27. 03. 2018.

Paper accepted: 12. 05. 2018.

Paper is available on the website: www.idk.org.rs/journal
}

quality of water and in particularly they provide open space and aesthetic value. Karavasta and Patoku lagoons are the main Albanian lagoons. Karavasta Lagoon is located in the central coast of Albania. It is bordered on north by Shkumbini River, on south Semani River and on the east are hills of Divjaka. Patoku Lagoon originates from the tectonic activities and the energy of Droj and Mat rivers. Flora and Fauna of lagoons is reached with a great number of species, creating important ecosystems of Albania. Karavasta Lagoon is protected by the Ramsar Convention of November 1995 [3,4]. The major water resource is surface water presented by lakes and rivers. Three main lakes of Albania are Shkodra Lake, Ohrid Lake and Prespa Lake. The most important rivers are: Drini, Mati, Ishmi, Erzeni, Shkumbini, Semani, Osumi, Vjosa, Bistrica and Buna [5]. The main rivers of Albania discharge into the Adriatic Sea.

Before 90' organochlorinated pesticides were used widely in Albania for agricultural purposes. The main agricultural areas were in the western of the country (Shkodra, Durresi, Tirana, Fieri, Lushnja, Vlora) but almost every were in the country had been developed different directions of 
agricultural (fruits, corns, vegetables, etc). The most used organochlorinated pesticides were DDT, Lindane, HCB, Aldrins and Heptachlors. The use of pesticides in Albania after the 1990 decreased rapidly due to migration of the population from villages to cities or immigration to other European countries. Liquid-Liquid Extraction (LLE) and Solid Phase Extraction (SPE) are the most frequently techniques used for analysis of semi-volatile organic pollutants in water samples. Large volume of samples needed because of low levels for organochlorine pollutants in water. These pollutants are lipophilic. Liquid-liquid extraction is a routine analysis used in many laboratories for isolation of organochlorine pollutants in water samples [6,7]. LLE is a low cost and rapid method.

\section{MATERIALS AND METHOD}

\subsection{Chemicals}

Hexane and Dichloromethane for pesticide residue grade were purchased from Sigma Aldrich. Anhydrous sodium sulfate $\left(\mathrm{Na}_{2} \mathrm{SO}_{4}\right)$, Florisil $(\geq 400$ Mesh ASTM) and silica gel (60-100 Mesh ASTM) were purchased also from Sigma Aldrich. $\mathrm{H}_{2} \mathrm{SO}_{4}$ with $95-97 \%$ purity for $\mathrm{GC}$ analyses was purchased by Merck. The sodium sulfate, florisil and silica gel were pre-extracted and rinsed with Hexane/Dichloromethane (4/1) just before utilization. Pesticide - Mix (31 compounds of organochlorine pesticides) were purchased from Sigma Aldrich. Standard solutions for all pollutants were prepared by dissolving their stock solutions in Hexane in different concentrations and storing them in refrigerator. All glassware was rigorously cleaned with detergent followed by pyrolysis at $220^{\circ} \mathrm{C}$. Procedural of blanks were regularly performed and all results presented are corrected for blank levels.

\subsection{Study areas}

The study area was Adriatic Sea (ports and lagoons) and rivers that discharge in it. The water samples were collected in three stations of Adriatic Sea (Vlora Bay - 12 samples, Porto-Romano - 9 samples, Port of Durres - 12 samples), in four rivers: Semani - 16 samples, Shkumbini - 12 samples, Erzeni - 12 samples and Mati - 13 samples (these rivers discharge in Adriatic Sea), and two main lagoons of Albania (Karavasta Lagoon - 16 samples and Patoku Lagoon - 15 samples). The samples were analyzed for a two years period, March 2014 - April 2016.

\subsection{Organochlorine pesticides analyze in water samples}

$1 \mathrm{~L}$ of water and $40 \mathrm{~mL} \mathrm{n}$-Hexane (extracting solvent) were added in a separator funnel. Liquidliquid extraction was used for the simultaneously extraction of organochlorine pesticide from water samples. The organic phase after separation was dried with $5 \mathrm{~g} \mathrm{Na}_{2} \mathrm{SO}_{4}$ anhydrous, for water removing. A Florisil column was used for the sample clean-up. After the concentration to $1 \mathrm{ml}$, the samples were injected in GC/ECD HP 6890 Series II. GC analyse were realized with split/splitless injector, Rtx-5 capillary column (30 m $\times 0.33 \mathrm{~mm} \times 0.25 \mu \mathrm{m}$ ) and micro-electron capture detector. Helium was used as carrier gas with 1 $\mathrm{ml} / \mathrm{min}$ and nitrogen as make-up gas with 24 $\mathrm{ml} / \mathrm{min}$. Injector and ECD temperature was hold respectively $280^{\circ} \mathrm{C}$ and $300^{\circ} \mathrm{C}$. Quantification of organochlorine peticides and their residues was performed in external standard. Five concentrations of pesticides mixture $(5,10,25,50$ and $100 \mathrm{ng} / \mathrm{ml}$ ) were used for calibration [3,8-10]. Analyzed organochlorine pesticides were: Group of CB - chlorinated benzene (HCB - Hexachlorobenzene, Tecnazene - tetrachloraniline and Quintozene - Pentachloronitrobenzene); Group of Lindane and its isomers (alfa- $\mathrm{HCH}$, beta- $\mathrm{HCH}$, gama- $\mathrm{HCH}$ - Lindane; delta-HCH and epsilon$\mathrm{HCH}$ ); Group of cyclopentadienyl pesticides: Group I (Heptachlor, Heptachlorepoxide and Chlordanes) and Group II (Aldrine, Isodrine, Dieldrine, Endrin and Endrin Aldehyd); DDTs (4,4-DDE; 4,4-DDD; 2,4-DDE; 2,4-DDD; 4,4-DDT, Dicofol and Methoxychlor) and Mirex (Mirex and Chlordecon).

\section{RESULTS AND DISCUSSION}

For two years period, 2014-2016, were analyzed samples from different important ecosystems of Albania. The water samples were collected in three ports (Vlora Bay, Porto-Romano, Port of Durres), in four rivers Semani, Shkumbini, Erzeni and Mati rivers, and two main lagoons of Albania (Karavasta and Patoku lagoons). Organochlorine pesticides and their degradation products were analyzed in 117 water samples. Table 1 shows the average concentrations of organochlorine pesticides founded in all stations of water samples.

The trend of OCPs was as follows; rivers > lagoon > sea. Higher level of organochlorine pesticides were found for Shkumbini River (199.4 $\mathrm{ng} / \mathrm{l})$ and the Semani River (171.8 ng/l), followed by the Karavasta Lagoon (110.8 $\mathrm{ng} / \mathrm{l})$. The main factor of higher concentrations of OCPs in river water can be their previous uses for agro-agricultural purposes. Rivers bring new inputs from rainfall and irrigation waters. Accidental pollution or recent use of pesticides can impact on differences between the stations. Figure 1 shown distribution of organochlorine pesticides in all studied stations. There are similarities in sea water samples, river samples and lagoon stations. This could be because the same pollution origin. For some 
stations of rivers were noted the presence of This could be connected with punctual sources in individual pesticides in higher levels than others. these stations or a momentum value.

Table 1. Average levels (ng/l) of individual organochlorine pesticides in water samples (Adriatic Sea, rivers and lagoons of Albania)

Tabela 1. Prosečni nivoi (ng / I) pojedinačnih organohlornih pesticida u uzorcima vode (Jadransko more, reke i lagune Albanije)

\begin{tabular}{|c|c|c|c|c|c|c|c|c|c|}
\hline & \multicolumn{3}{|c|}{ Adriatic Sea, Albania } & \multicolumn{4}{|c|}{ Rivers of Albania } & \multicolumn{2}{|c|}{$\begin{array}{l}\text { Lagoons of } \\
\text { Albania }\end{array}$} \\
\hline & $\begin{array}{l}\text { VLW } \\
\text { (12 st.) }\end{array}$ & $\begin{array}{l}\text { PRW } \\
\text { (9 st.) }\end{array}$ & $\begin{array}{l}\text { PDW } \\
\text { (12 st.) }\end{array}$ & $\begin{array}{l}\text { SEW } \\
\text { (16 st.) }\end{array}$ & $\begin{array}{l}\text { SHW } \\
\text { (12 st.) }\end{array}$ & $\begin{array}{l}\text { ERW } \\
\text { (12 st.) }\end{array}$ & $\begin{array}{l}\text { MAW } \\
\text { (13 st.) }\end{array}$ & $\begin{array}{c}\text { KLW } \\
\text { (16 st.) }\end{array}$ & $\begin{array}{l}\text { PLW } \\
\text { (15 st.) }\end{array}$ \\
\hline Tecnazene & 9.43 & 1.17 & 0.36 & 3.02 & 12.30 & 2.59 & 7.21 & 5.49 & 2.62 \\
\hline $\mathrm{a}-\mathrm{HCH}$ & N.D. & 7.45 & 5.32 & 1.34 & 9.37 & N.D. & 0.28 & 0.14 & 1.13 \\
\hline $\mathrm{HCB}$ & 4.83 & 2.21 & 0.27 & 6.42 & 9.45 & 2.06 & 0.23 & 0.14 & 0.10 \\
\hline $\mathrm{b}-\mathrm{HCH}$ & N.D. & 5.06 & 0.22 & 12.79 & 6.90 & 2.34 & N.D. & 0.14 & 0.35 \\
\hline Lindane & 2.33 & 4.07 & 1.65 & 8.02 & N.D. & 1.20 & N.D. & 0.41 & 0.38 \\
\hline Quintozene & 13.80 & N.D. & 0.04 & 3.58 & 2.50 & 6.34 & N.D. & 0.39 & 0.24 \\
\hline $\mathrm{d}-\mathrm{HCH}$ & 0.54 & 7.43 & 3.24 & 4.25 & 0.20 & N.D. & N.D. & 0.33 & N.D. \\
\hline $\mathrm{e}-\mathrm{HCH}$ & 11.60 & 3.58 & 4.27 & 1.72 & 8.47 & 3.24 & N.D. & 0.37 & 0.15 \\
\hline Heptachlor & 0.17 & 0.28 & 0.35 & 2.17 & 10.40 & 1.27 & 3.43 & 3.43 & 1.27 \\
\hline Aldrine & 0.31 & 4.34 & 0.07 & 0.54 & 4.90 & N.D. & 1.53 & 28.31 & 1.40 \\
\hline Isodrine & 0.65 & 0.29 & 1.60 & 11.60 & 4.40 & N.D. & 3.87 & 1.21 & N.D. \\
\hline Oxychlordane & N.D. & 0.90 & 0.85 & 8.36 & 8.70 & 2.35 & 3.01 & 10.30 & 1.38 \\
\hline $\begin{array}{l}\text { Heptachlorepoxid } \\
\text { e cis }\end{array}$ & 0.46 & 1.14 & 2.89 & 5.81 & 5.80 & 5.27 & 3.21 & 4.49 & 6.25 \\
\hline $\begin{array}{l}\text { Heptachlorepoxid } \\
\text { e trans }\end{array}$ & N.D. & 5.11 & 1.74 & N.D. & 5.70 & 3.27 & 4.11 & 4.14 & 2.70 \\
\hline Chlordan trans & 0.16 & 3.48 & 1.66 & N.D. & 13.26 & 3.54 & 7.85 & 1.23 & N.D. \\
\hline 2,4'-DDE & 0.45 & 0.58 & 2.23 & 2.85 & N.D. & N.D. & N.D. & 3.36 & 2.32 \\
\hline Endosulfan alfa & 0.85 & 0.21 & 2.36 & 0.84 & 25.10 & N.D. & N.D. & 1.26 & 0.53 \\
\hline Chlordan cis & 1.12 & 0.39 & N.D. & 12.53 & 14.10 & 7.86 & 2.10 & 3.39 & 0.08 \\
\hline Dieldrin & 1.39 & N.D. & 0.86 & 11.31 & N.D. & 3.76 & N.D. & 1.55 & 5.37 \\
\hline 4.4'-DDE & 5.97 & 6.28 & 1.65 & 2.60 & 9.54 & 12.60 & 0.06 & 7.55 & 3.11 \\
\hline 2.4-DDD & 2.31 & 0.80 & 15.05 & 26.22 & 4.54 & 1.02 & 9.10 & 1.96 & 1.12 \\
\hline Endrin & 0.44 & 0.55 & 0.28 & N.D. & 11.70 & 3.10 & N.D. & 3.80 & 0.17 \\
\hline Endosulfan beta & 0.45 & 3.83 & N.D. & 4.18 & 13.30 & 1.25 & 6.32 & 1.55 & 0.46 \\
\hline 4.4-DDD & 0.85 & 5.75 & 0.01 & 4.61 & 0.50 & 3.68 & 2.42 & 10.91 & 1.56 \\
\hline 2.4-DDT & 1.12 & 1.36 & 0.01 & 0.64 & 3.20 & 0.25 & 0.12 & 0.65 & 0.47 \\
\hline Chlordecon & 1.39 & N.D. & 0.75 & N.D. & N.D. & 2.10 & 1.23 & 1.85 & 0.30 \\
\hline Endosulfan sulfat & N.D. & 0.35 & 0.15 & 0.96 & 2.10 & 6.95 & 1.57 & 2.79 & 3.83 \\
\hline 4,4'-DDT & 0.23 & 1.71 & 1.06 & 1.54 & 1.87 & 0.66 & 1.67 & 3.49 & 2.35 \\
\hline Dicofol & N.D. & 0.45 & 1.28 & 3.37 & 7.64 & 2.50 & N.D. & 1.67 & N.D. \\
\hline Methoxychlor & N.D. & 0.52 & N.D. & 24.13 & N.D. & 8.47 & 10.05 & 2.12 & 0.37 \\
\hline Mirex & 4.37 & 5.08 & 6.38 & 6.44 & 3.50 & 3.50 & 13.53 & 2.34 & 0.86 \\
\hline$\sum \mathrm{OCP}$ & 65.22 & 74.37 & 56.58 & 171.84 & 199.44 & 91.17 & 82.90 & 110.76 & 40.87 \\
\hline $\mathrm{CB}$ & 28.06 & 3.38 & 0.67 & 13.02 & 24.25 & 10.99 & 7.44 & 6.02 & 2.96 \\
\hline$\sum \mathrm{HCH}$ & 14.47 & 27.59 & 14.7 & 28.12 & 24.94 & 6.78 & 0.28 & 1.39 & 2.01 \\
\hline$\sum$ Heptachlors & 1.91 & 11.3 & 7.49 & 28.87 & 57.96 & 23.56 & 23.71 & 26.98 & 11.68 \\
\hline$\sum$ Aldrins & 2.79 & 5.18 & 2.81 & 23.45 & 21 & 6.86 & 5.4 & 34.87 & 6.94 \\
\hline$\sum$ DDTs & 10.93 & 17.45 & 21.29 & 65.96 & 27.29 & 29.18 & 23.42 & 31.71 & 11.3 \\
\hline$\sum$ Endosulfans & 1.3 & 4.39 & 2.51 & 5.98 & 40.5 & 8.2 & 7.89 & 5.6 & 4.82 \\
\hline Mirex & 5.76 & 5.08 & 7.13 & 6.44 & 3.5 & 5.6 & 14.76 & 4.19 & 1.16 \\
\hline
\end{tabular}




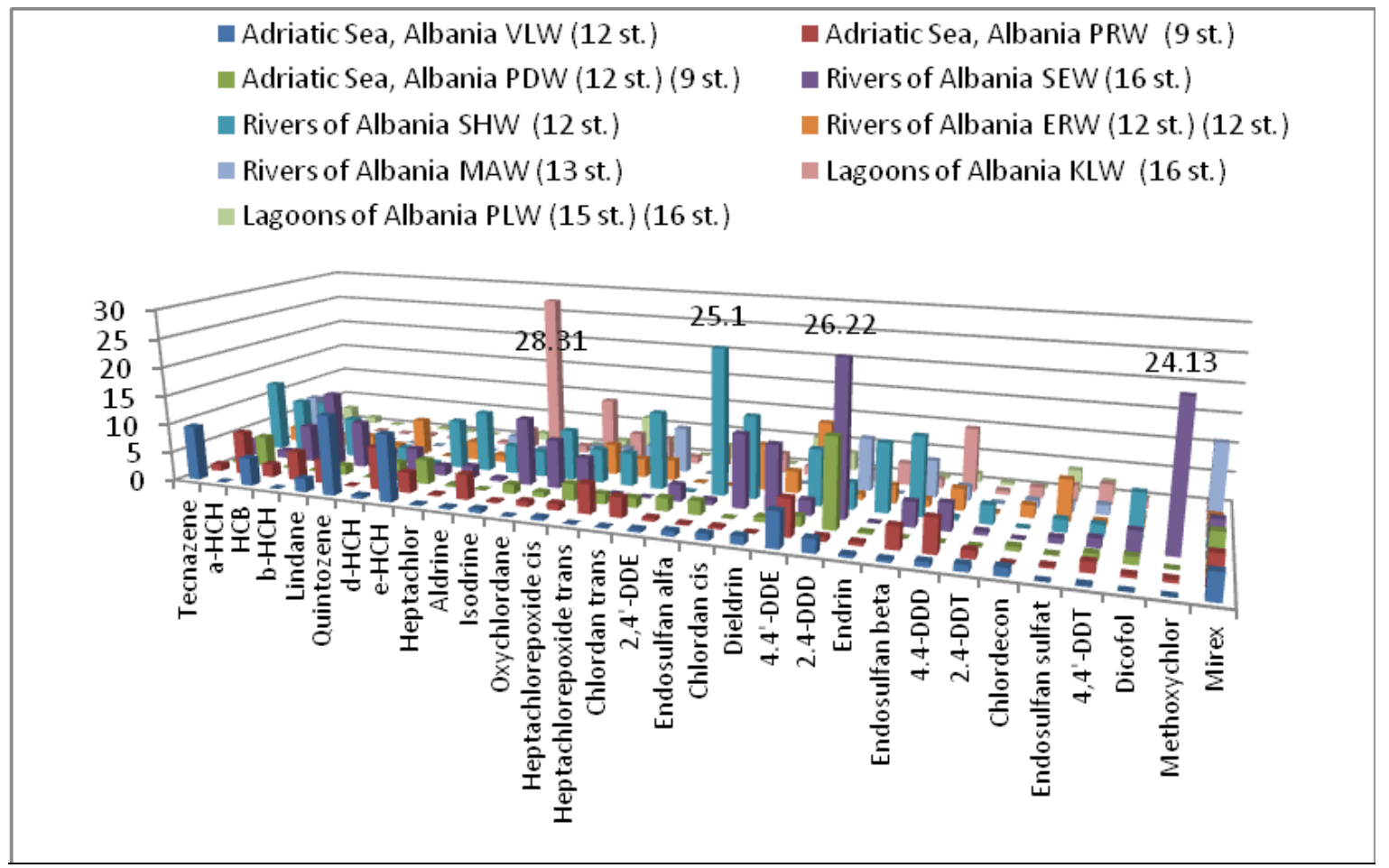

Figure 1. Distribution of organochlorine pesticides and their residues in water samples of Albania Slika 1. Distribucija organohlornih pesticida i njihovih ostataka u uzorcima vode u Albaniji

Concentration of Hexachlorobenzene, Quintozene (Pentachloronitrobenzene) and Tecnazene (Tetrachloronitrobenzene) in all water samples was shown in Figure 2. Vlora station was more polluted followed by Shkumbini and Semani rivers. Tecnazene was found almost for all stations.
Hexachlorobenzene was found for $50 \%$ of samples. HCB level was found for all stations lower than permitted levels for surface waters according EU Directive 2013/39 [11]. Quintozene levels were higher in Vlora Bay and Erzeni River.

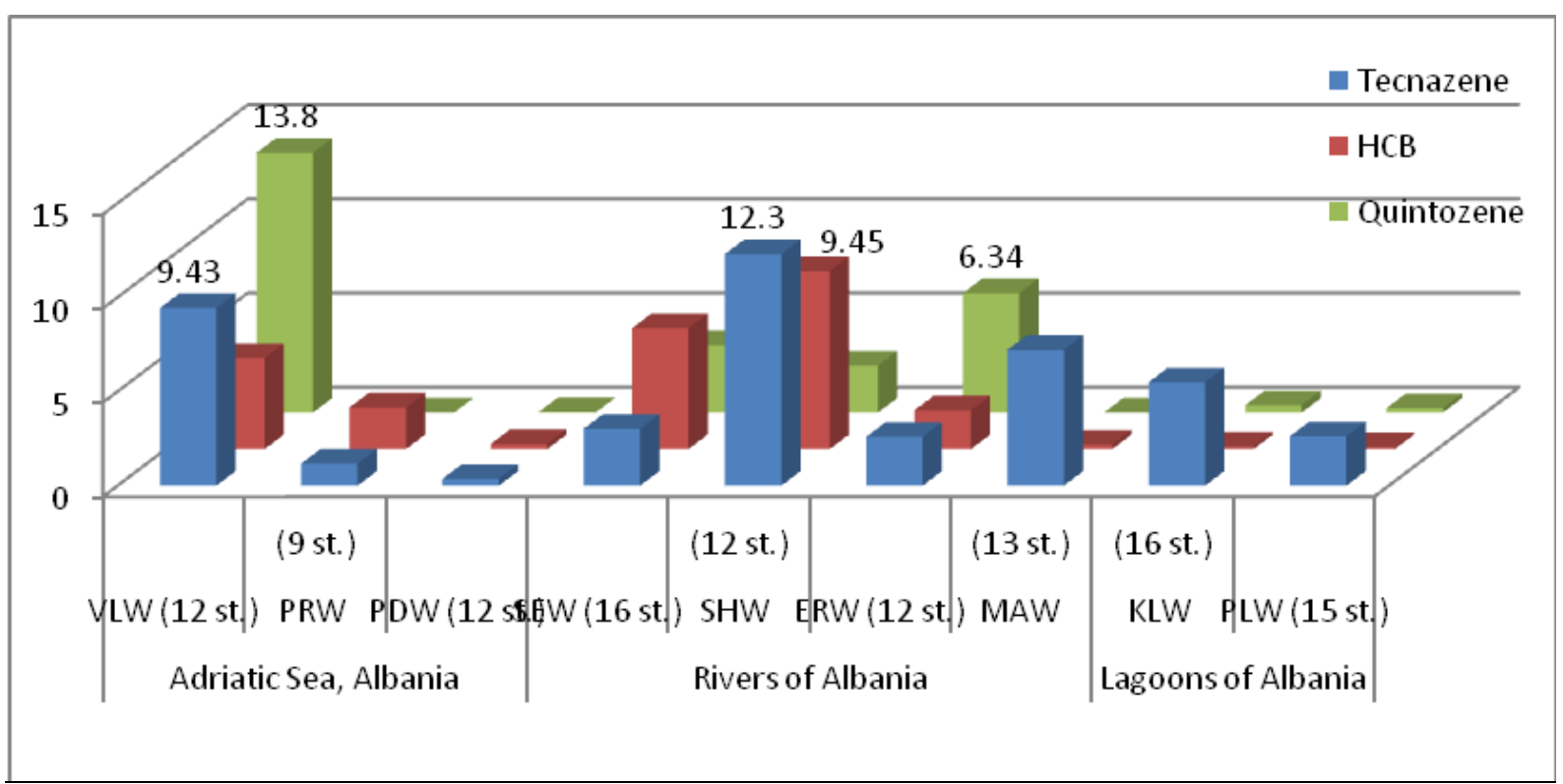

Figure 2. Hexachlorobenzene and its similar pesticides in water samples of Albania

Slika 2. Heksahlorobenzen i slični pesticidi u uzorcima vode u Albaniji

Concentrations of Lindane and its isomers (hexachlorocyclohekzanes-HCHs) were shown in Figure 3. 


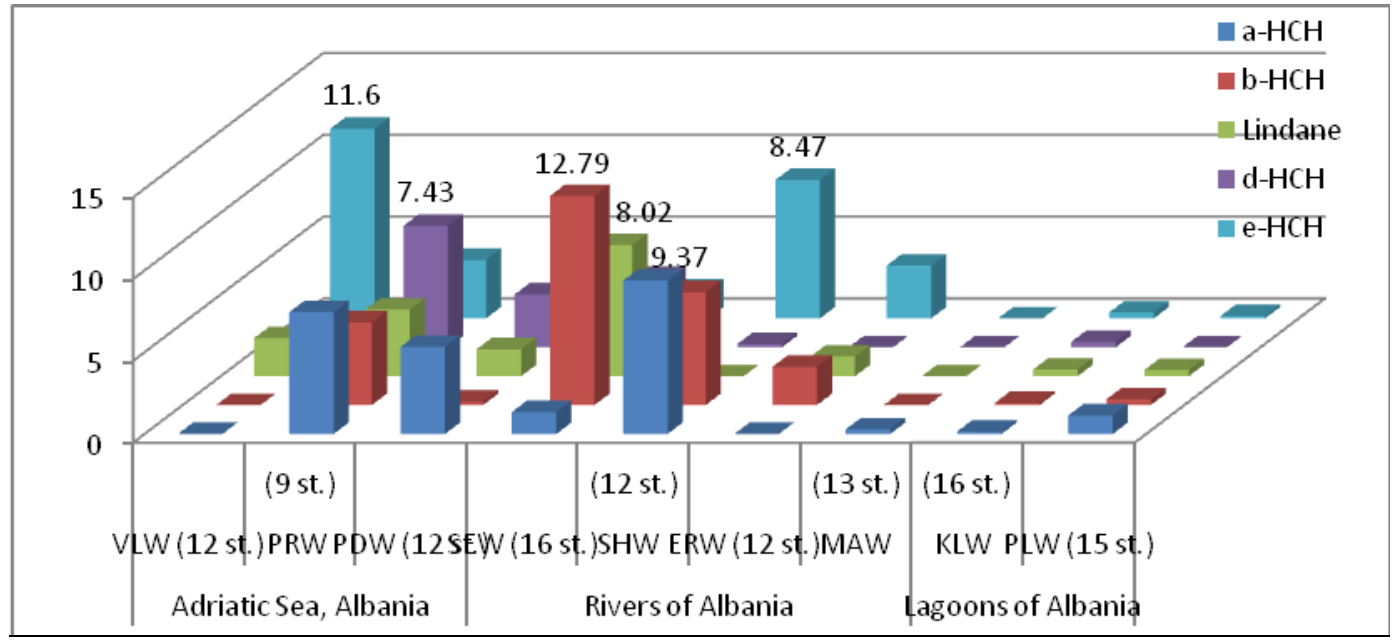

Figure 3. Lindane and its isomers in water samples of Albania

Slika 3. Lindan i njegovi izomeri u uzorcima vode Albanije

Adriatic Sea stations (Vlora, Durres and PortoRomano) and river stations (Semani and Shkumbini) were most polluted with $\mathrm{HCHs}$ (15 to $27 \mathrm{ng} / \mathrm{l})$. It was noted that Lindane concentration wasn't the isomer of $\mathrm{HCHs}$ in higher concentration. Alfa-, beta-, delta- and epsilon- $\mathrm{HCH}$ were found in $60 \%$ of samples. Their origin could be because of their presence as impurity in Lindane formulations or because of Lindane degradation process. Other $\mathrm{HCHs}$ could be also products of degradation of other pesticides or because of impact of urban waste especially in rivers water. Only for some stations their levels were higher than permitted level $(10 \mathrm{ng} / \mathrm{l})$. For all stations, total of $\mathrm{HCH}$ sere lower than permitted level of $0.04 \mathrm{ug} / \mathrm{l}$ conform EU Directive 2013/39 and Albanian norms. Chlordane's and Heptachlors are halogenated cyclopentadiene pesticides. Their levels were higher in river stations and Karavasta Lagoon (Figure 4).

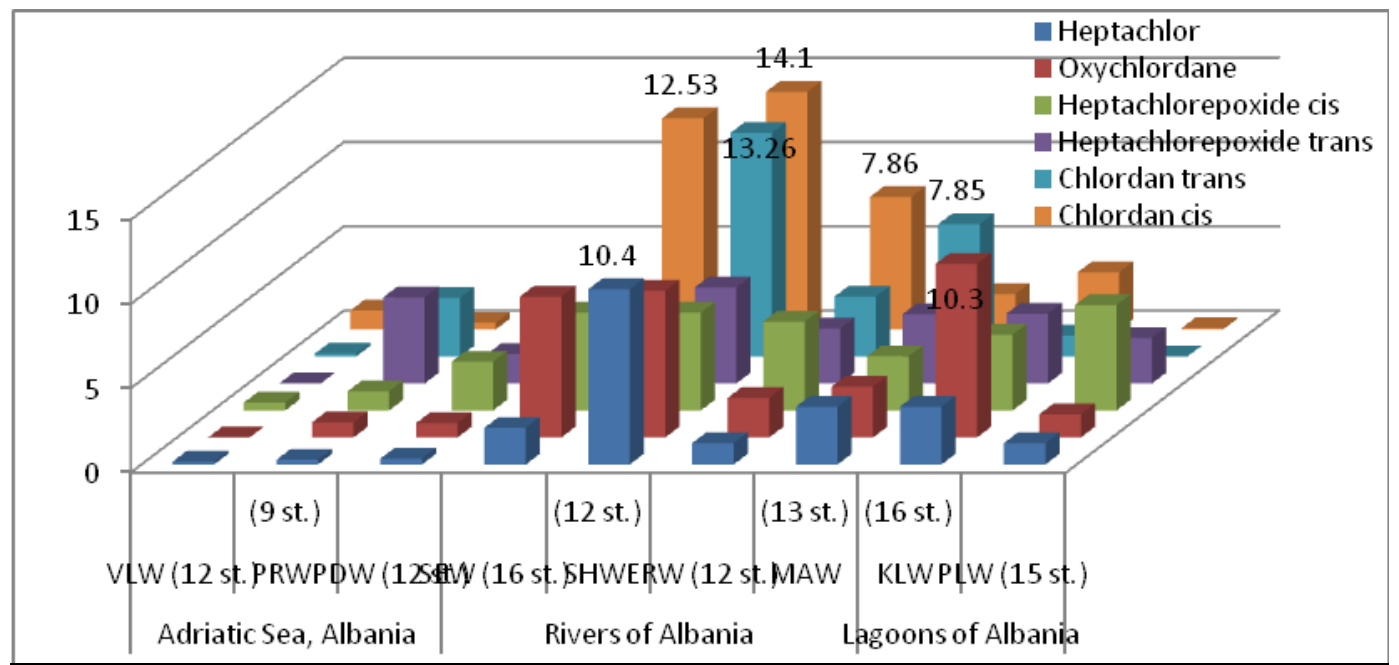

Figure 4. Cyclopentadiene pesticides in water samples of Albania Slika 4. Ciklopentadienski pesticidi u uzorcima vode u Albaniji

Total of cyclopentadiene pesticides (Group I) were higher in Shkumbini River (56 ng/l). Chlordane was found in higher levels in Shkumbini and Semani rivers. This pesticide could be recently in use in agricultural areas near these rivers. Heptachlor were found only in Shkumbini River samples. The higher levels were found for its degradation products. This fact is connected with previous use of Heptachlor. Higher levels of degradation products of cyclopentadiene pesticides were found for both lagoons. Heptachlors and Chlordanes weren't found in sea water samples. Levels of Heptachlors in some stations of Shkumbini and Semani rivers were 2-3 times higher than EU Directive 2013/39 or Albanian norms. Group II of cyclopentadiene pesticides, Aldrines, were shown in Figure 5. 


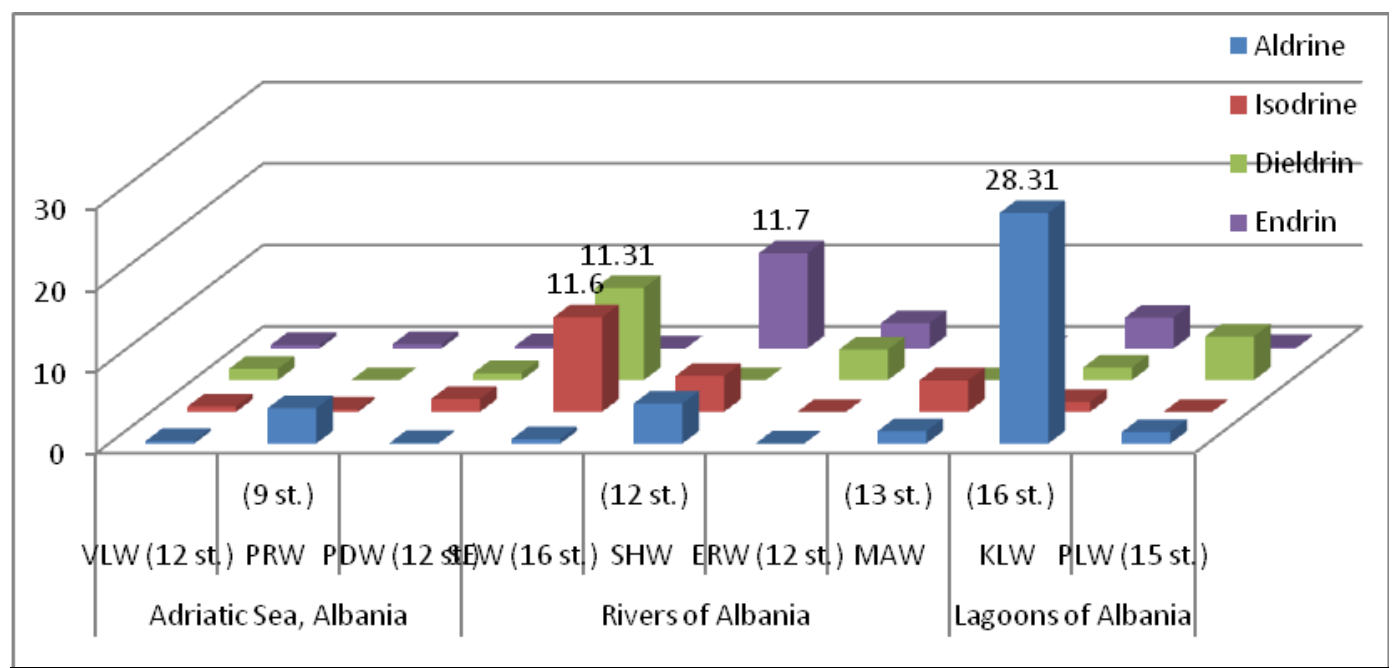

Figure 5. Aldrines in water samples of Albania

Slika 5. Aldrini u uzorcima vode u Albaniji

The higher levels of Aldrines were for Karavasta Lagoon with $34.87 \mathrm{ng} / \mathrm{l}$. In fact the higher level it was only for Aldrine pesticide. This is connected with recent use of Aldrine in the agricultural areas near Karavasta Lagoon. Aldrines weren't dedected in sea water samples. Dieldrin and Isodrine were found in Semani River while
Endrin was found in Shkumbini River. Dieldrin, Isodrin and Endrin are degradable products of Aldrine. Some stations of Karavasta Lagoon, Semani and Shkumbini rivers Aldrines were 2-5 times higher than EU directive 2013/39 and Albanian norms. Concentrations of DDTs were shown in Figure 6 for all stations.

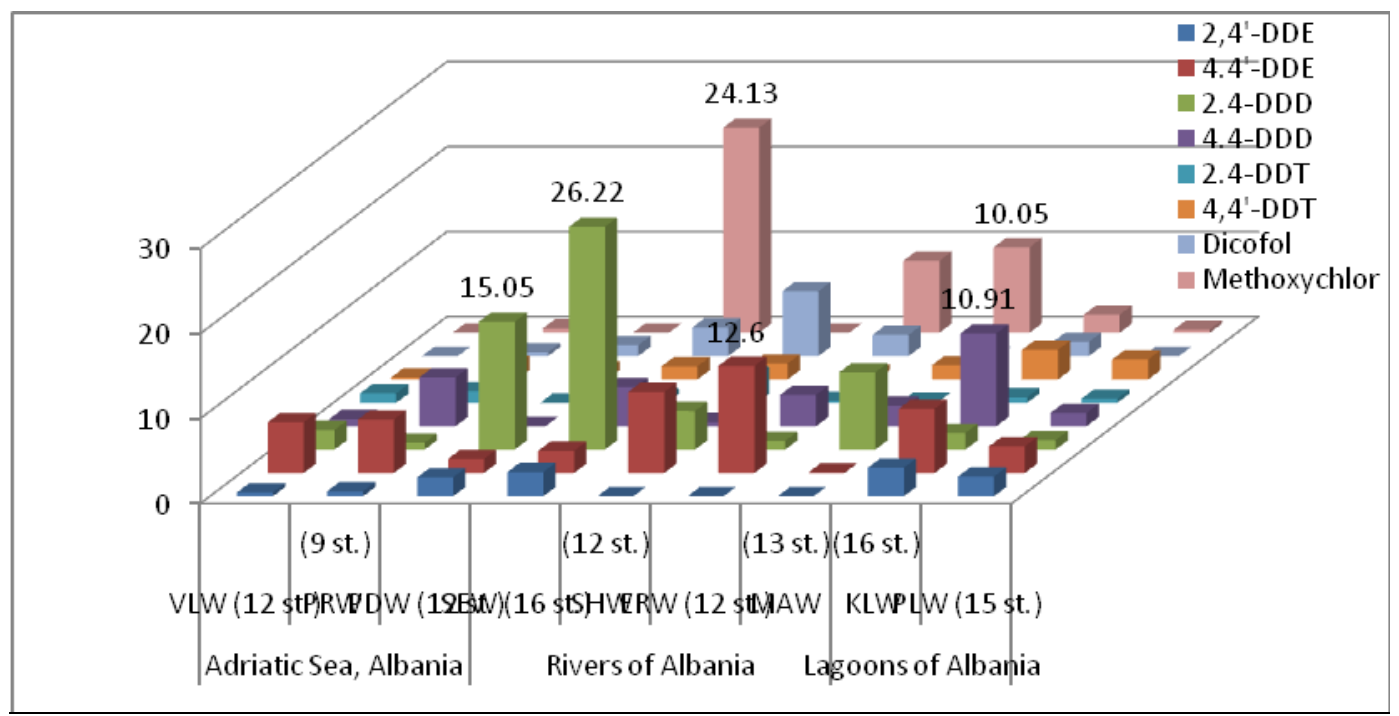

Figure 6. DDTs in water samples of Albania

Slika 6. DDTs u uzorcima vode u Albaniji

The higher level of DDTs was for Semani River because of previous use of DDTs in the agricultural areas of Myzeqeja fields. DDT was found on 25\% of samples. Its levels were lower than $1 \mathrm{ng} / \mathrm{l}$ for all stations. 4,4'-DDT were lower than permitted level of $0.01 \mathrm{ug} / \mathrm{L}$. Degradable products of DDT (DDD and DDE) were found in higher level. DDTs profiles were: DDD > DDE > Methoxychlor > Dicofol > DDT. Note that DDE was reported as main contributors of DDTs in sediments and biota samples because their stability. This rate was found for marine samples. 2,4'-DDD was found in higher level in Semani River and port of Durres while 4,4'-DDD was found in higher level in Karavasta Lagoon. Methoxychlor, a substituent of 
DDT, was found in higher level in Semani River and Karavasta Lagoon. This fact is connected with use of this pesticide recent years in these areas. New arrival from Semani River can affected Karavasta Lagoon. DDE was third contributor in surface waters. Erzeni and Shkumbini rivers were the most polluted systems. Total of DDTs were higher than permitted levels $(0.025 \mathrm{ug} / \mathrm{l})$ in Shkumbini River and Karavasta Lagoon samples. These ecosystems could be most polluted because of the main agricultural areas for their water basins. Endosulfans concentrations were presents in Figure 7.

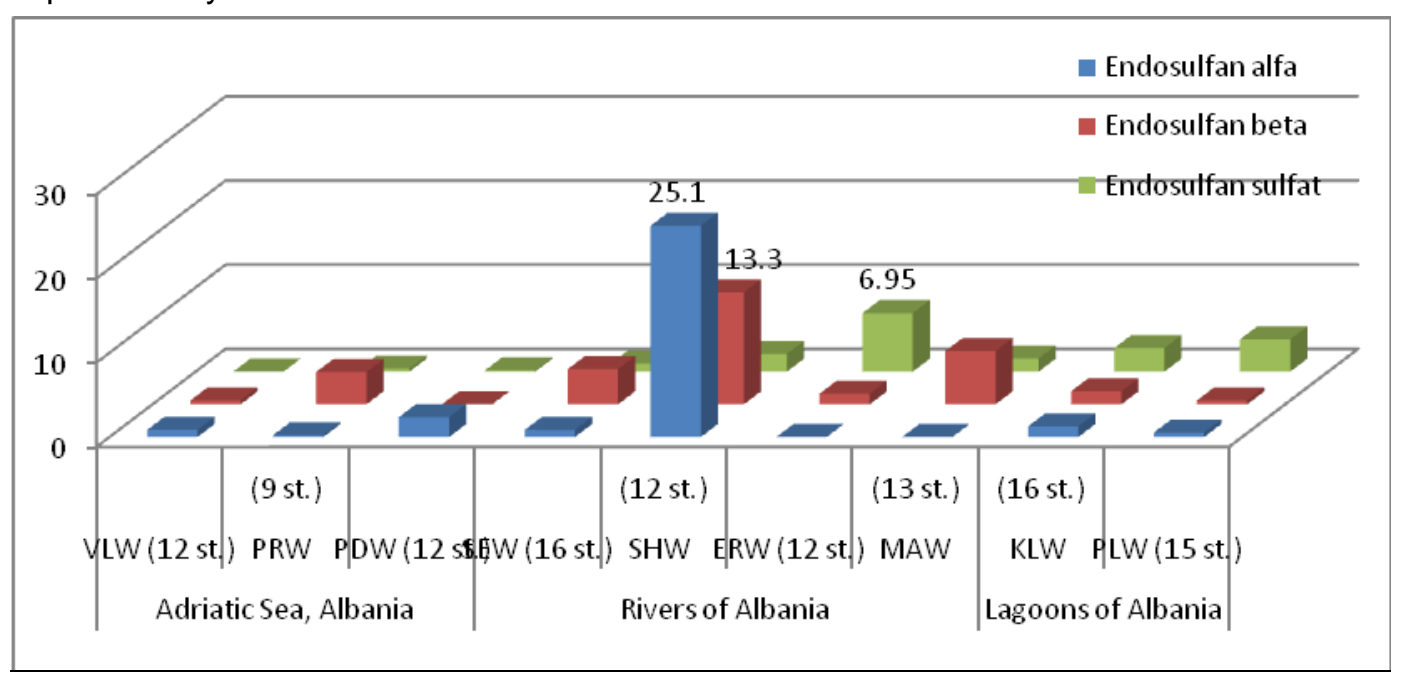

Figure 7. Endosulfanes in water samples of Albania

\section{Slika 7. Endosulfani u uzorcima vode Albanije}

Total of Endosulfans were around 10 higher in Shkumbini River $(40.5 \mathrm{ng} / \mathrm{l})$ than other stations. Note that Endosulfans were found in higher level only for two station of Shkumbini River. This fact suggests punctual source of Endosulfan's in this ecosystem. For water samples of Shkumbini River the levels of Endosulfans were higher than permitted level based on EU Directive 2013/39. Alfa- and beta-Endosulfans were the main contributors. It does not exclude the recent use of
Endosulfan in water basin of Shkumbini River. For other ecosystems Endosulfans were found in lower level. Mirex and Chlordecon concentrations in analyzed water samples were shown in Figure 8. The higher level was for Mati River (14.7 ng/l). The main contributors for all samples was Mirex. These pesticides were not in use in Albania in the past. Mirex and Endosulfans could be in use in these areas under false trade name.

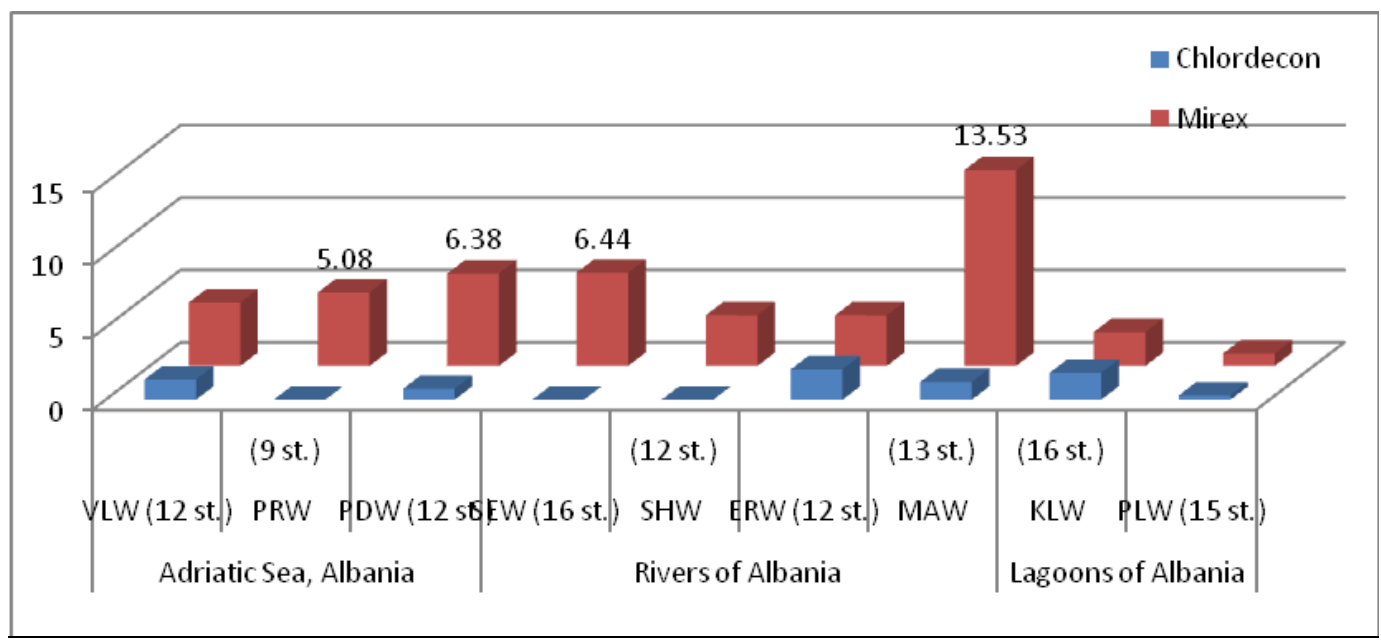

Figure 8. Mirex and chlordecon in water samples of Albania

Slika 8. Mireks i hlordekon u uzorcima vode u Albaniji 


\section{CONCLUSIONS}

The highest level of contamination with organochlorine pesticides were found in the rivers $>$ lagoon > sea. Total of organochlorine pesticides were higher for Shkumbini and the Semani River followed by the Karavasta Lagoon. The organochlorine pesticide levels were higher in rivers compared to lagoons and seawater because of new arrivals of pesticides from soil irrigation from rainfalls. OCPs concentrations in Karavasta Lagoon were higher than Patoku Lagoon. This is related to the geographic position of these two lagoons and influence of Shkumbini and Semani rivers. There are similarities in sea water samples, river samples and lagoon stations. This could be because the same pollution origin. For some stations of rivers were noted the presence of individual pesticides in higher levels than others. This could be connected with punctual sources in these stations or a momentum value. It was noted presence of pesticide residues in higher level than pesticides. This fact is connected with previous use of pesticides in Albania. Concentration of Organochlorine pesticides and their residue concentrations were found for all stations lower than permitted levels for surface waters according EU Directive 2013/39. Exceptions were for some individual pesticides found in isolated stations in higher levels than permitted levels. Mirex and Endosulfans could be in use in some areas under false trade name. Organochlorine pesticides concentrations were found to be in lower levels than reported data on previous studies for the same stations.

\section{REFERENCES}

[1] I.Corsi, A.Tabaku, A.Nuro, S.Beqiraj, E.Marku, G.Perra, L.Tafaj, D.Baroni, D.Bocari, C.Guerranti, A.Cullaj, M.Mariottini, L.Shundi, V.Volpi, S.Zucchi, A.Pastore, A.lacocca, A.Trisciani, M.Graziosi, M.Piccinetti, T.Benincasa, S.Focardi (2010) Ecotoxicologial assessment of Vlora Bay (Albany) by a biomonitoring study using an integrated approach of sub-lethal toxicological effects and contaminants levels in bioindicator species, Journal of Coastal Research, Special Issue 58 - Coastal Research in Albania: Vlora Gulf [Tursi \& Corselli], p. $116-120$.
[2] A.Çullaj, A.Hasko, A.Miho, F.Schanz, H.Brandl, R.Bachofen (2005) Overview on Albanian natural waters and the human impact, Environment International, 31(1), 133-146.

[3] A.Nuro, E.Marku, M.Shehu (2012) Organochlorine pesticide residues in marine water in the South of Albania, International Journal of Ecosystems and Ecology Sciences (IJEES), 2(1), 27-34.

[4] B.Murtaj, E.Çomo, A.Nuro, E.Marku, A.Emiri (2013) Evaluation of Organochlorine Pesticides Residues and PCBs in Sediments of Karavasta Lagoon, Albania, Journal of International Envriomental Application and Sciences (JIEAS), 8(4), 573-579.

[5] E.Como, A.Nuro, B.Murtajn, E.Marku, A.Emiri (2013) Study of Some Organic Pollutants in Water Samples of Shkumbini River, International Journal of Ecosystems and Ecology Sciences (IJEES), 8(4), 573-579.

[6] I.Konstantinou, D.Hela, T.Albanis (2006) The status of pesticide pollution in surface waters (rivers and lakes) of Greece. Part I. Review on occurrence and levels, Environmental Pollution, 141(3), 555-570.

[7] D.Wells, P.Hess (2000) Determination and evaluation of chlorinated biphenyls. In: Barceló $E$ (2007) Sample handling and trace analysis of pollutants, techniques, applications and quality assurance. Elsevier, Amsterdam; p.239-285.

[8] Th.Lekkas, G.Kolokythas, A.Nikolaou, M.Kostopoulou, A.Kotrikla, G.Gatidou, N.Thomaidis, S.Golfinopoulos, C.Makri (2004) Evaluation of the pollution of the surface waters of Greece from the priority compounds of List II, 76/464/EEC Directive, and other toxic compounds, Environment International, 30(8), 995-1007.

[9] Z.Vryzas, G.Vassiliou, C.Alexoudis, E.Papadopoulou-Mourkidou (2009) Spatial and temporal distribution of pesticide residues in surface waters in northeastern Greece, Water Research, 43(1), 1-10.

[10] E.Gustafson, M.Dickhut (1997) Distribution of polycyclic aromatic hydrocarbons in southern Chesapeake Bay surface water: evaluation of three methods for determining freely dissolved water concentrations, Environment Toxicology Chemistry, 16, 452-461.

[11] Directive 2013/39/EU Of The European Parliament and of the Council of 12 August 2013, amending Directives 2000/60/EC and 2008/105/EC as regards priority substances in the field of water policy. 


\section{IZVOD}

\section{ORGANOHLORNI PESTICIDI I NJIHOVI REZIDUALI U POVRŠINSKIM VODAMA ALBANIJE}

Ova rad istražuje koncentracije organohlornih pesticida $i$ njihovih reziduala $u$ nekim vodnim ekosistemima u Albaniji. Uzorci vode sakupljeni su u tri luka Jadranskog mora (Luke Vlora, Drač $i$ Porto-Romano), u četiri reke (reke Semani, Shkumbini, Erzeni i Mati) i dve glavne lagune Albanije (lagune Karavaste i Patoku). 117 uzoraka vode analizirano je za period od dve godine (mart 2014 - april 2016). Kvalitativna i kvantitativna analiza 31 organohlornih pesticida i njihovi ostataka, na bazi EPA 8081B Metoda, su realizovani korišćenjem tehnike gasne hromatografije sa detektorom detektovanja elektrona. RTKS-5 kapilarna kolona je korišćena za razdvajanje organohlornih jedinjenja.

Veće koncentracije organohlornih pesticida pronađene su za uzorke vode reka Shkumbini $i$ Semani i Karavasta laguna zbog njihove prethodne upotrebe. Reziduali pesticida bili su na višem nivou od pesticida jer predstavljaju ostatke procesa degradacije pesticida. Neki pojedinačni pesticidi su pronađeni u većim koncentracijama na nekim stanicama. To može biti zbog tačnih izvora ili nedavne upotrebe ovih pesticida. Utvrđene koncentracije organohlornih pesticida su na nižim nivoima od prijavljenih podataka iz prethodnih ispitivanja za iste stanice.

Ključne reči: organohlorni pesticidi; Jadransko more; Albanske reke; lagune; analiza vode; GC/ECD.

Naučni rad

Rad primljen: 27. 03. 2018.

Rad prihvaćen: 12. 05. 2018.

Rad je dostupan na sajtu: www.idk.org.rs/casopis

(C) 2018 Authors. Published by Engineering Society for Corrosion. This article is an open access article distributed under the terms and conditions of the Creative Commons Attribution 4.0 International license (https://creativecommons.org/licenses/by/4.0/) 